Article

\title{
Sustainability of Public Finance through the Lens of Transfer Prices and Their Associated Risks: An Empirical Research
}

\author{
Mihaela Paraschiva Luca ${ }^{1, *}$ and Ileana Tache ${ }^{2}$ \\ 1 Doctoral Studies Department, Lucian Blaga University of Sibiu, 550024 Sibiu, Romania \\ 2 Faculty of Economic Sciences and Business Administration, Transilvania University of Brasov, \\ 500036 Brasov, Romania; ileanatache@unitbv.ro \\ * Correspondence: mihaela.manta@ulbsibiu.ro
}

\section{check for}

updates

Citation: Luca, M.P.; Tache, I. Sustainability of Public Finance through the Lens of Transfer Prices and Their Associated Risks: An Empirical Research. Sustainability 2021, 13, 6837. https://doi.org/ $10.3390 /$ su13126837

Received: 27 April 2021

Accepted: 11 June 2021

Published: 17 June 2021

Publisher's Note: MDPI stays neutral with regard to jurisdictional claims in published maps and institutional affiliations.

Copyright: (c) 2021 by the authors. Licensee MDPI, Basel, Switzerland. This article is an open access article distributed under the terms and conditions of the Creative Commons Attribution (CC BY) license (https:// creativecommons.org/licenses/by/ $4.0 /)$.

\begin{abstract}
At a time when the world economy is being affected by the COVID-19 pandemic, we are more aware than ever of the importance of the sustainability of public finances. This paper outlines its importance by discussing transfer prices and their fiscal associated risks. In the current economic context, marked by the crisis and by an increasing pressure from the control authorities on companies, no matter how important the theoretical research, it cannot capture very well the pulse of practical activity. Under these conditions, empirical studies are becoming increasingly important, requiring an approach to practical economic reality. In order to analyze the way in which companies that carry out transactions with affiliated parties approach the transfer prices and the risks related to them, we conducted an empirical, quantitative research using the CAWI method (Computer Assisted Web Interviewing) and the questionnaire. The research results demonstrate an awareness by the responding companies of the importance of transfer pricing and their risks, the transactions most prone to control in this area being those of financing within the group, followed equally by management services, consulting, assistance and transactions with goods. In the face of legislation that leaves room for interpretation and a high number of controls on transfer pricing, a small number of companies participating in the research have used the Advance Price Agreement as a tool to reduce the tax risk associated with transfer pricing. Companies also face uncertainty about how ongoing global tax reforms will affect them in the coming period.
\end{abstract}

Keywords: transfer pricing; empirical research; affiliated companies; fiscal authorities

\section{Introduction: Transfer Pricing and Sustainability of Public Finance}

Transfer prices are defined in the Fiscal Code [1] as the prices at which "tangible or intangible goods are transferred or services are provided" between companies that are part of the same group, also called affiliates.

According to the definition of the Organization for Economic Co-operation and Development [2], which outlines the relevant legislation, transfer prices are "prices at which an enterprise transfers physical goods, intangible assets or provides services to affiliated enterprises".

In the Report on the macroeconomic situation for 2020 and its projection for 2021-2023 [3], prepared by the Government of Romania-Ministry of Public Finance, among the strategic objectives on short and medium term of ANAF in the field of tax evasion and tax fraud reduction, we can find the making of tax inspections in compliance with the BEPS Plan (Base Erosion Profit Shifting) and the ATAD Directive (European and international regulations on preventing and combating tax evasion), as well as increasing controls on transfer pricing.

From the idea above, in 2020 the MFP (Ministry of Public Finance) Order no. 3281/2020 modified the format of the informative statement 394-regarding deliveries/provisions made on the national territory by persons registered for VAT purposes, by reporting in the form the transactions with affiliated persons made in the reporting period [4]. The amended format of the declaration helps tax authorities make it easier to identify taxpayers who are 
involved in related party transactions and can be selected for a possible tax inspection. The purpose stated in the report approving the amendment of Declaration 394 is to extend the risk analysis to multinational companies, which have registered a development in Romania recently and hold a significant percentage of the value of transactions.

The measures taken aimed at intensifying control actions in the field of transfer pricing, which was achieved, as shown by the data published by ANAF in the Activity Report for 2019 [5] and the Report on the macroeconomic situation on year 2021 and its projection for the years 2022-2024, elaborated by the Government of Romania-Ministry of Finance [6]. We observed an increase of 135.42\% in 2020 (RON 158.2 million) compared to 2019 (RON 67.2 million) in the additional fiscal obligations established representing profit and accessories tax; respectively, an increase of $79.2 \%$ in tax loss occurred as a result of controls in the field of transfer pricing (year 2020: RON 981.1 million, year 2019: RON 547.5 million).

In the current period, when control authorities are interested in increasing revenue collected to budgets and transfer pricing is an area of interest, it is important for managers to know the main types of transactions verified by authorities and the risks associated with them. Only through proper management of related party transactions can risks be reduced and adjustments proposed by supervisory authorities avoided.

At a time when the world economy is being affected by the COVID-19 pandemic, we are more aware than ever of the importance of the sustainability of public finances. In times of crisis, there is a strong test for the sustainability of public finances, i.e., for the government's ability to effectively manage risky situations (which can generate economic or social imbalances) without major interventions on expenditures, revenues or budget deficit [7]. The government, through the fiscal-budgetary policy measures taken, aims to ensure economic macro-stabilization, which is a premise of a viable economic growth.

Romania's general consolidated budget for 2021 is achieved on a cash deficit of $7.16 \%$ of Gross Domestic Product (GDP). According to the opinion of the Fiscal Council of Romania on the State Budget Law, the Social Insurance Budget Law for 2021 and the Fiscal-Budgetary Strategy 2021-2023 [8], a budgetary consolidation necessarily involves an increase in budget revenues in various ways, such as streamlining collection, diversifying the tax base, reducing the opportunities used by some taxpayers to evade paying taxes and duties, reducing tax evasion and fraud, and optimizing tax rates and taxation, respectively.

From the perspective of transfer pricing, the sustainability of public finances is ensured through actions undertaken both by ANAF and by companies that carry out transactions with related parties.

In the context of limited budgetary resources, the intensification of control actions in the field of transfer pricing is a priority action for ANAF Romania, which has a series of easy-to-use reporting tools for identifying fiscal risk in the field of transfer pricing and initiating controls, such as: information in the financial statements on related parties and income tax, transactions with related parties reported to the Bucharest Stock Exchange, Country by Country Reporting, Statement 394, Reporting information on cross-border reporting arrangements (DAC6).

Companies can contribute to ensuring the sustainability of public finances by raising awareness of the importance of transfer pricing, compliance with relevant legislation, compliance with the market value principle, avoiding actions to shift profits between tax jurisdictions with different tax rates so as to ultimately minimize tax for profit, as well as through the correct preparation of reports. Due to the transfer pricing legislation, which is very controversial compared to the tax legislation, the preparation and provision of specific reports can be a financial burden for the company; however, at the same time, they contribute to increasing transparency and creating a favorable image in relation to the general public.

The goal of this paper is to analyze, in the spirit of sustainability of public finance, the way in which companies that carry out transactions with affiliated parties approach transfer prices and their associated risks. The paper is organized as follows: the next 
section depicts a brief literature overview, Section 3 explains the research methodology, Section 4 presents the results of the empirical research (Figures 1-15), Section 5 tries to identify some limits of the research and Section 6 concludes the paper.

We present below the results of this empirical research, which is based on the answers received to 70 questionnaires, out of the 95 sent online:

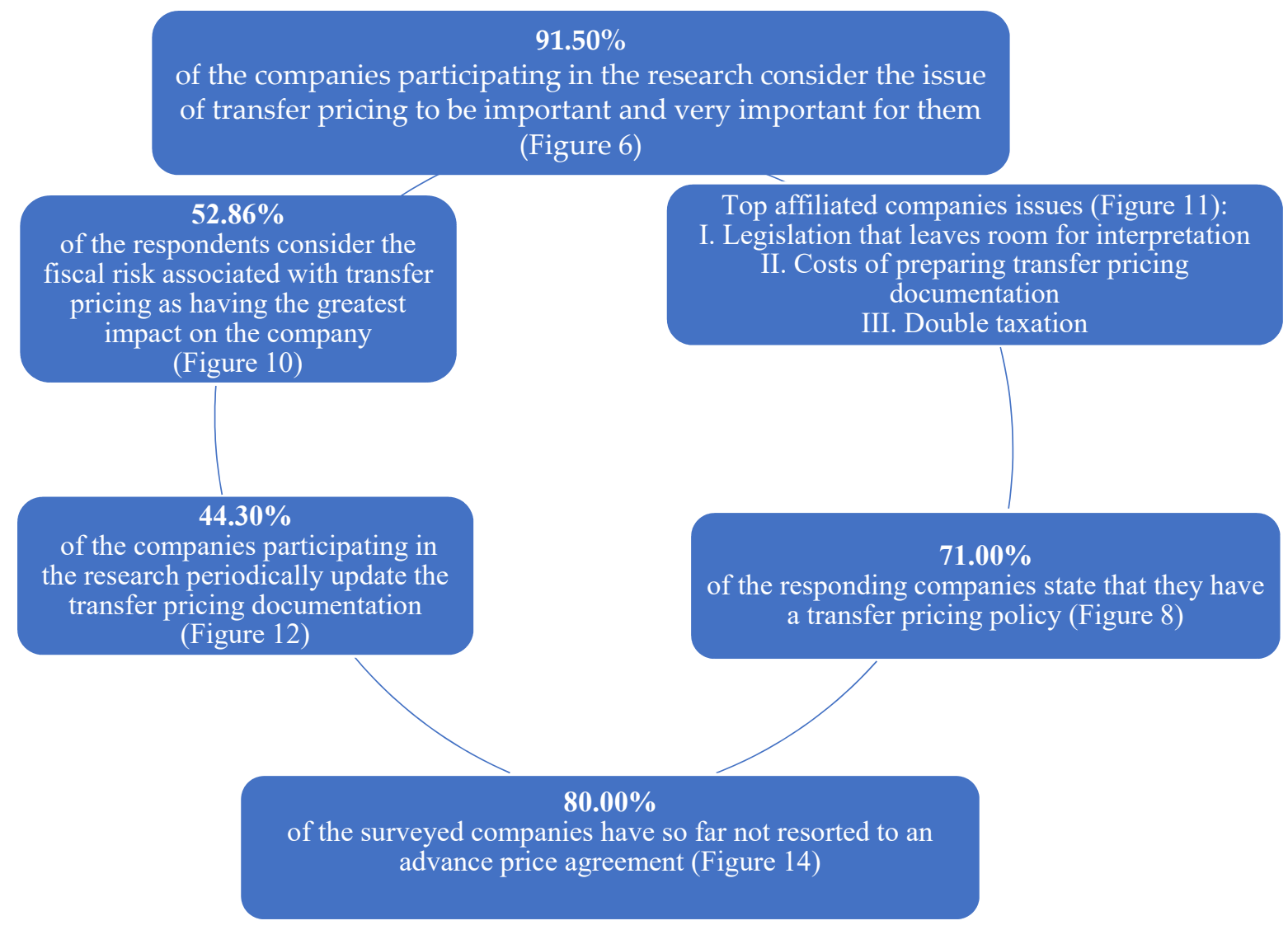

Figure 1. The main conclusions of the research.

\section{Literature Overview}

As defined by the European Commission [9], public finance sustainability, also referred to as fiscal sustainability, is the ability of a government to sustain its current spending, tax and other policies in the long run without threatening the government's solvency or without defaulting on some of the government's liabilities or promised expenditures.

Through some of its practices, transfer pricing affects the capacity to extract taxation from the economy, and thus, implicitly, public finance sustainability. Davies et al. [10] studied tax avoidance through transfer pricing. They found no evidence of tax avoidance if disregarding tax haven destinations and showed that the cumulative tax losses from transfer pricing is quite large. Nonetheless, by appropriately targeting enforcement, a significant increase in revenues may be achieved.

At the same time, companies are aware about the government concern in the field of transfer pricing and about the increased focus of tax authorities on profit transfers and all fiscal aspects of intra-group transactions. Bloomberg Tax [11], acknowledging that COVID-19 disrupted and further complicated the never-simple world of transfer pricing, outlines what tax departments need to do to prepare for scrutiny by tax authorities hoping to squeeze revenue out of transfer pricing in 2021.

According to ICAEW [12], a solution for achieving sustainable public finances is rebuilding public trust and confidence in governments. People with the technical knowledge 
and skill in accountancy can help governments regain control of public finances. Policy makers should consider more attentively the importance of financial risk and reporting standards (issues addressed by our research).

Recently, several studies have been carried out on transfer pricing. Large-scale studies are those performed by large audit firms, which have rich experience in this direction. We exemplify in this sense the accounting company Ernst \& Young, which, with a periodicity of 2-3 years, radiographs the transfer prices globally. Its latest study is for 2019, entitled "Transfer Pricing and International Tax Survey-How profound change, transparency and controversy are reshaping a critical business function" [13], which includes 700 responses from people with leadership positions in taxation and transfer pricing in America, Europe and Asia-Pacific. These types of surveys played a particularly important role in identifying key trends as well as the risks and opportunities associated with transfer pricing.

In 2020, KPMG Company published the results of a study called "Transfer Pricing and Trade Compliance Survey" [14], which included over 110 companies of various sizes and belonging to different industries. This study provides information on how companies handle, manage and react to transfer price adjustments from a fiscal and customs perspective.

Another recent study, "International Tax Survey Priorities and challenges facing multinationals2019/2020" [15], belongs to the company Baker Tilly International and had respondents from North America, Latin America, EMEA (Europe, Middle East, Africa) and APAC (Asia-Pacific). The study focused, in addition to transfer pricing, on other issues facing multinational companies. Of the 10 subjects of the study, two make direct reference to transfer pricing: compliance obligations and disputes with the authorities. This study also compiled a list of the 10 topics addressed. Within the top-ranked ones, the obligations to comply with transfer pricing are in 2nd place, and disputes with transfer pricing authorities are in 3rd place. In the survey on transfer pricing compliance obligations, respondents were asked to rate the level of importance of transfer pricing compliance challenges for their business. Regarding the disputes with the authorities in the field of transfer pricing, the respondents were asked to classify the challenges related to the settlement of the disputes with the authorities.

A scientific study entitled "Transfer pricing: Strategies, practices, and tax minimization" [16], conducted in collaboration with the Tax Executives Institute (TEI), with the involvement of 219 directors, demonstrates the role that transfer prices play in minimizing taxes, as well as the interest of multinationals to comply with international tax law.

The analysis of 274 publicly listed companies in Indonesia showed that sales transactions with related parties negatively influence the value of the company. In addition, corporate social responsibility reporting has the role of reducing the negative influences of related party transactions. Debts between related parties have a positive influence on the value of the company, proof that the market perceives loans between related parties as beneficial. Regulators should pay more attention to transfer pricing reports that tend to become abusive [17].

In Romania, too, we have identified studies in the field of transfer pricing, conducted by large audit and tax consulting companies. Relevant in this sense is the study conducted in 2018 and 2020 by the company PKF Finconta and called "Transfer prices in Romania" [18], which aimed at identifying the evolution of the important issues in the field of transfer prices in Romania.

Taking into account the recent steps taken by the control authorities in the field of transfer pricing, we considered it appropriate to conduct a topical empirical research, with companies operating mainly in the Sibiu area, in different sectors of activity, various sizes and structure of capital, but which have something in common: they carry out transactions with related parties in crisis conditions generated by the COVID-19 pandemic and, at the same time, have to be prepared at any time for a possible control in the field of transfer pricing. 


\section{Research Methodology}

To achieve the set objectives, we conducted an empirical, quantitative research. As a research method we chose to use the questionnaire, and as a quantitative research technique we used CAWI (Computer Assisted Web Interviewing).

This study did not require the review and approval of the Ethics Committee for the following reasons: the questionnaire was anonymous, and the respondents completed it by entering each individually the computer application People friendly forms and surveys, available at https:/ / www.typeform.com/ (accessed on 2 January 2021). Accessing the application implies consent. In the centralized situation of the received answers, the name of the respondent company cannot be identified, which guaranteed the respondents' privacy.

We developed a heuristic research, but considering it not only as a research method based on discovering new knowledge, but also an art to discover the opinions of our respondents. Our research involves not only a simple interpretation of the questionnaire results, but also the way of conceiving those questions, a strategy based on experience, practice and observation of facts.

Of course, this kind of heuristic method is not guaranteed as being optimal, but sufficient for immediate objectives and for finding solutions for specific issues.

Quantitative research aims to obtain objective information from representative samples of subjects and is used in order to obtain concrete conclusions, which can be reported numerically to the target population. The essence of quantitative research is to use a theory to understand the verified problem [19].

So, we opted for the CAWI method of distributing the questionnaire, considering the conditions under which the study can be performed with minimal risks in the epidemiological context related to the pandemic caused by the appearance and spread of the new coronavirus (COVID-19). Through this online method of conducting the study [20], the respondent downloads the questionnaire from the site indicated in the email and completes it electronically, not requiring the physical presence of the interviewer. The main advantages of this method are:

- There are no limitations in the use of presentation materials: audio, video, images, graphics, etc.;

- Offers the possibility to study delicate, sensitive, personal topics, which would hardly be obtained in the presence of the interviewer;

- Can communicate with respondents whose attitude is relatively evasive;

- Ensures convenience for the respondent;

- The geographical boundaries of communication are exceeded;

- The information is easily collected and processed;

- Financial and time costs are low.

The questionnaire is a logical sequence of questions [21], with which we gathered information on the awareness of companies that conduct transactions with related parties of the importance of transfer pricing and their risks and includes a number of 14 questions. The questionnaire on transfer pricing and related risks was completed using the computer application, People friendly forms and surveys, available at https:/ / www.typeform.com/ (accessed on 2 January 2021).

Between November 2020 and December 2020, a number of 95 questionnaires were sent to affiliated companies from the private and public sector, which operate mainly in the Sibiu area of Romania. Answers from 70 questionnaires were received from companies whose general characterization data are presented in Figures $2-5$ below. What characterizes the elaborated questionnaire is the anonymity and the fact that all the answers are confidential. The main elements specific to this questionnaire are:

- Questions were included both in closed format (single answer and multiple answer) and in open format; 
- The open format questions concerned general information such as the function of the respondent within the company and the field of activity of the company; the rest of the questions were in closed format;

- There was a grading question where respondents were asked to give grades from 1 (lowest impact) to 3 (highest impact), in order to facilitate its completion as much as possible and to be able to quantify the answers;

- $\quad$ To certain questions where there were 5 possible answers, respectively 4 variants were delimited (depending on the pursued objective), on a scale of values from 1 to 5, according to the Likert Scale, where 1 represents the maximum level of agreement, 5 the maximum level of disagreement, 3 the neutral value, and 2 and 4 are intermediate levels of agreement or disagreement. The respondent can choose only one answer option.

The group directly interested in the transfer prices and the risks related to them were established, to whom the questionnaire is addressed, in particular companies that have transactions with related parties, regardless of the size of the company or the capital structure (Romanian, foreign or mixed).

From a methodological point of view, the survey research technique involves the use of the sample as a research tool. The sample is a part of the population or community, which is extracted to reflect the main features of the general population [22]. The sample is made on the basis of specific procedures, in order to ensure representativeness, such as: random surveys, guided surveys, mixed surveys, simple surveys or multistage surveys. In our study we opted for a sample built by the random survey procedure, in which each member of the population has equal chances to be selected. In order to establish the statistical population of the companies included in the sample, a documentation activity was performed by:

- Analysis of the financial statements submitted to the Sibiu National Agency for Fiscal Administration, in order to identify the companies that reported for 2018 revenues from affiliated entities, respectively expenses in relation to affiliated entities (ANAF website);

- Analysis of the nominal list of large taxpayers administered by the General Directorate for Administration of Large Taxpayers (ANAF website) to identify those in Sibiu County;

- Discussions and analyses with representatives of local audit and accounting companies; - $\quad$ Analysis of companies using the site www.listafirme.ro (accessed on 2 November 2020);

- Information collected from the Bucharest Stock Exchange website, www.bvb.ro (accessed on 2 November 2020), regarding the transactions with the affiliated parties reported by the listed companies.

The main characteristics of quantitative research are: objectivity, deducibility and generalization [23]. Taking into account the characteristics of the statistical population, we established the composition of the sample so that the results obtained can be extrapolated to the whole group. A number of 95 questionnaires were sent, the volume of the sample being 95 respondents from the private and public sector. The structure of the sample is shown in Table 1 below: 
Table 1. Sample structure.

\begin{tabular}{|c|c|c|c|c|}
\hline & \multirow{2}{*}{ The Company's Turnover } & \multirow{2}{*}{$\begin{array}{l}\text { Questionnaires } \\
\text { Sent-Number }\end{array}$} & \multicolumn{2}{|c|}{ Questionnaires Received } \\
\hline & & & No. & Percentage \\
\hline 1. & Less than 500 thousand euros & \multirow{5}{*}{95} & 11 & $15.71 \%$ \\
\hline 2. & 500 thousand-1 million euros & & 6 & $8.57 \%$ \\
\hline 3. & 1-10 million euros & & 29 & $41.43 \%$ \\
\hline 4. & More than 10 million euros & & 24 & $34.29 \%$ \\
\hline & Total & & 70 & $100.00 \%$ \\
\hline
\end{tabular}

The response rate to the questionnaires is $74 \%$ of the total sample initially established, which leads to the idea that the results obtained are considered relevant and can be extended to the entire statistical population.

\section{Empirical Research}

The empirical research carried out between November 2020 and December 2020 aims to analyze the way in which companies operating mainly in the Sibiu area of Romania and conducting transactions with related parties, regardless of company size or capital structure (Romanian, foreign or mixed), address prices transfer and the risks associated with them.

The transfer price adjustments established by ANAF following tax inspections performed on different companies (see Table 2 below) create the impression that companies that have transactions with related parties give low importance to transfer prices and the risks associated to them. Our objective is to verify whether or not this is the case.

Table 2. Evolution of transfer pricing adjustments.

\begin{tabular}{ccc}
\hline Year & $\begin{array}{c}\text { Additional Tax Obligations } \\
\text { Established (Profit and Accessories } \\
\text { Tax)-Million Lei }\end{array}$ & $\begin{array}{c}\text { Reduction of Fiscal } \\
\text { Losses-Million Lei }\end{array}$ \\
\hline 2010 & 13.8 & 5.9 \\
\hline 2011 & 66.6 & 188 \\
\hline 2012 & 11 & 100 \\
\hline 2013 & 4 & 72 \\
\hline 2014 & 28 & 60 \\
\hline 2015 & 192 & 334 \\
\hline 2016 & 87 & 428.1 \\
\hline 2017 & 60 & 316.4 \\
\hline $2018^{*}$ & 149.3 & 237.7 \\
\hline 2019 & 67.2 & 547.5 \\
\hline $2020^{* *}$ & 158.2 & 981.1 \\
\hline
\end{tabular}

Source: own processing of the data provided by ANAF press releases, Annual Performance Reports, www.anaf.ro (accessed on 2 November 2020) and [24]. * For the year 2018, we obtained data related to the period JanuaryNovember 2018 from the "Budget fiscal strategy for the period 2019-2021" elaborated by the Romanian Government. The month December 2018 was estimated quantitatively based on information related to January-November 2018 [25]. ** Report on the macroeconomic situation for 2021 and its projection for 2022-2024, prepared by the Government of Romania-Ministry of Finance [6]. 
The purpose of this research is to answer the question: are affiliated companies aware of the importance of transfer pricing and associated risks and are they acting accordingly for their proper management? Using the computer application, People friendly forms and surveys, we generated in Excel a summary with the answers received. These were interpreted according to the own professional reasoning and theoretical knowledge, doubled by practical experience, using the computer application mentioned above and by making graphic images. The descriptive analysis of the results of the questionnaire was performed based on the data and information stated above.The following graphs present general data of characterization of the companies that participated in the research:

An important share in the sample is represented by companies with Romanian capital, followed by those with foreign and mixed capital (Figure 2).

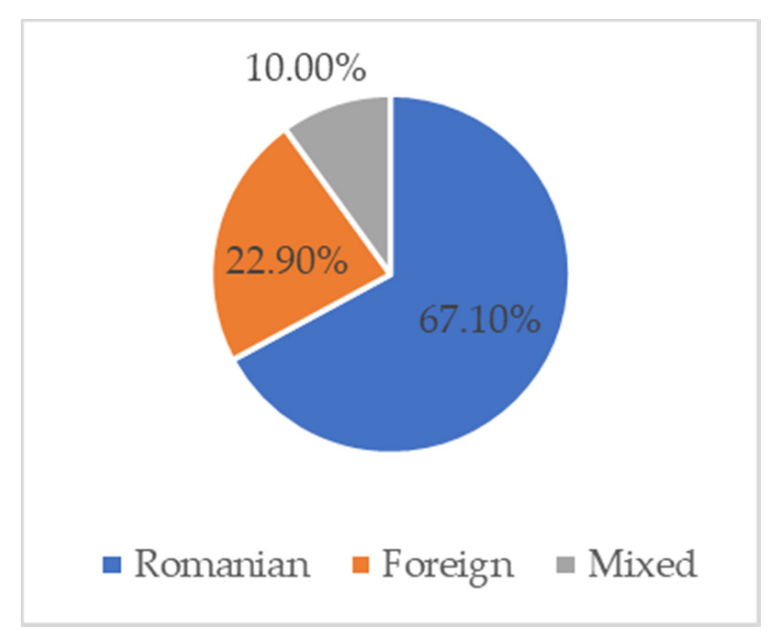

Figure 2. Structure of the company capital.

According to the information presented above, $75.7 \%$ of the affiliated companies participating in the study have a turnover of more than EUR 1 million, $15.7 \%$ of the companies have a turnover of less than EUR 500 thousand, while the companies with a turnover between EUR 500 thousand and EUR 1 million represent $8.6 \%$ of the surveyed companies (Figure 3).

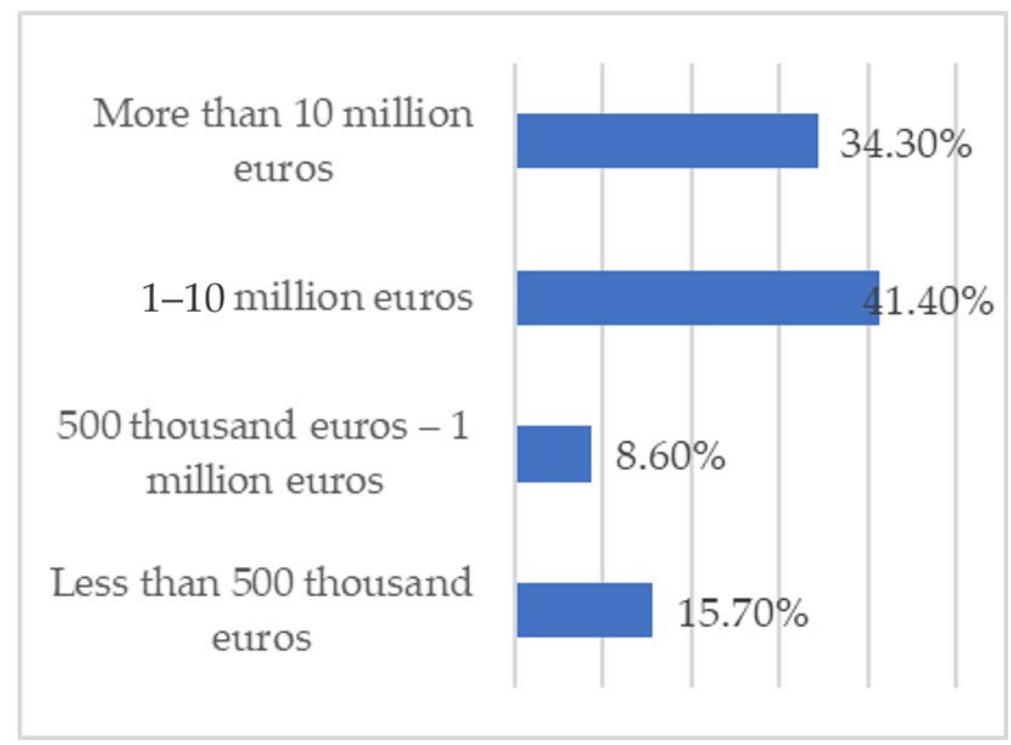

Figure 3. Turnover of the company. 
The questionnaires were completed in a percentage of $82.86 \%$ by staff with expertise in the financial-accounting field, and in the case of $11.43 \%$ by the administrator. Only in the situation of $5.71 \%$ of the companies, the questionnaires were filled out by other people (Figure 4).

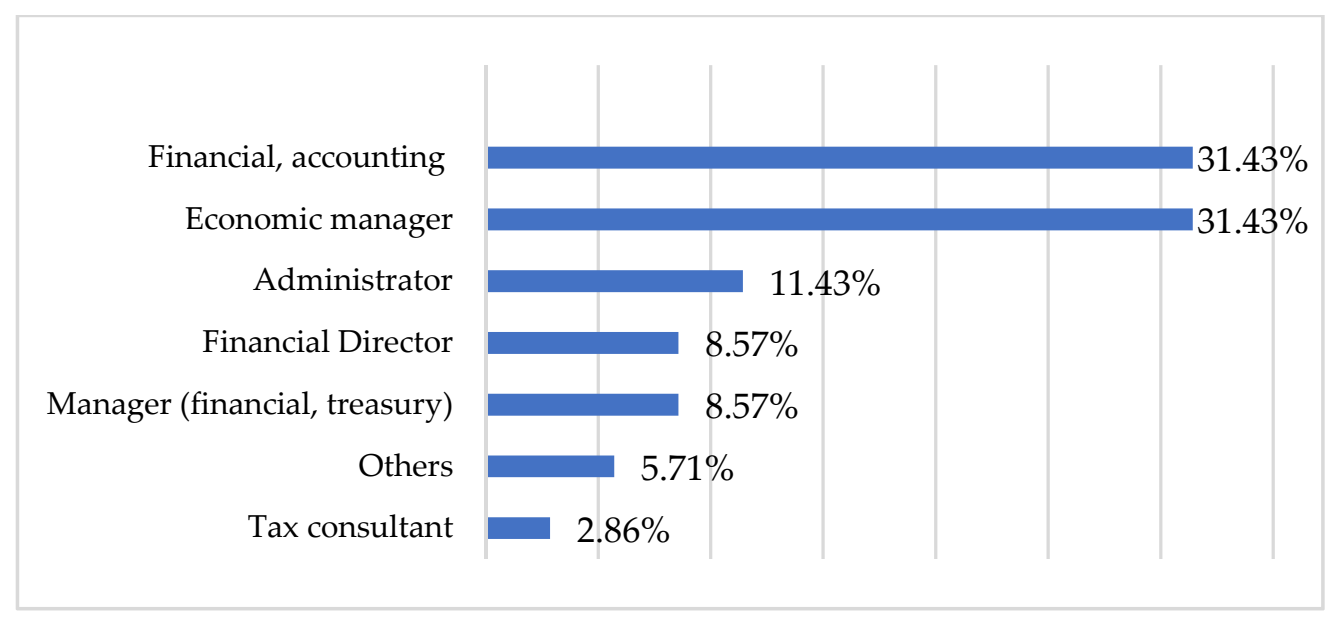

Figure 4. Function of the person who completed the questionnaire.

Companies operating in the field of production represent $34.29 \%$ of the surveyed companies. The fields of activity trade and services are equal, each holding $12.86 \%$, followed by constructions with a percentage of $11.43 \%$ and by companies in the field of tourism, agriculture/food industry with $5.71 \%$ each. The other fields of activity represent $17.14 \%$ (Figure 5).

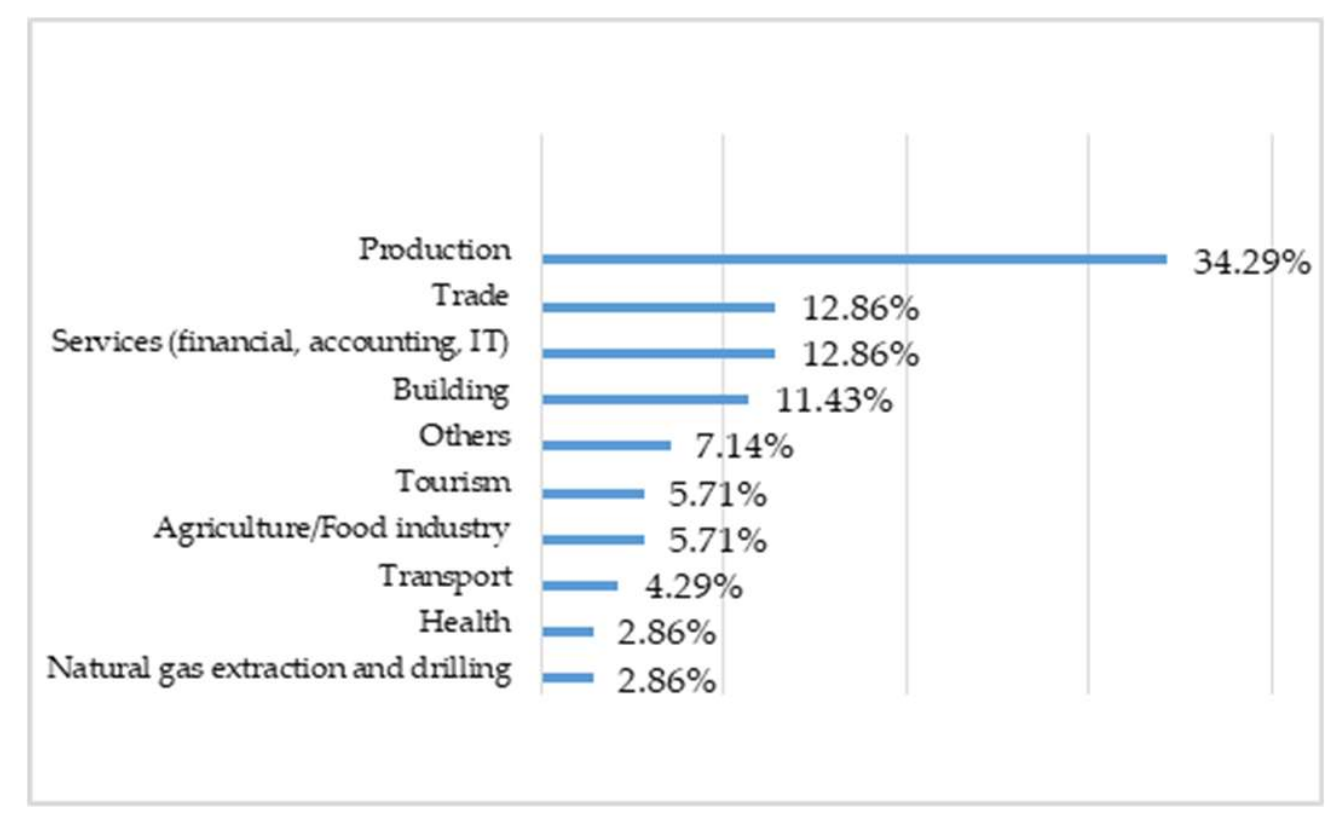

Figure 5. The field of activity of the company.

The results of the detailed analysis of the questionnaires are presented as follows:

1. In the context of the increasing number of transfer pricing controls, how important do you consider the issue of transfer pricing for your company?

A total of $91.50 \%$ of the companies participating in the research consider the issue of transfer pricing to be important and very important for them. Only $7.10 \%$ of the surveyed 
companies consider the transfer prices to be insignificant for them, while $1.40 \%$ cannot comment on this issue. Interestingly, none of the companies surveyed consider transfer prices to be at all important (Figure 6).

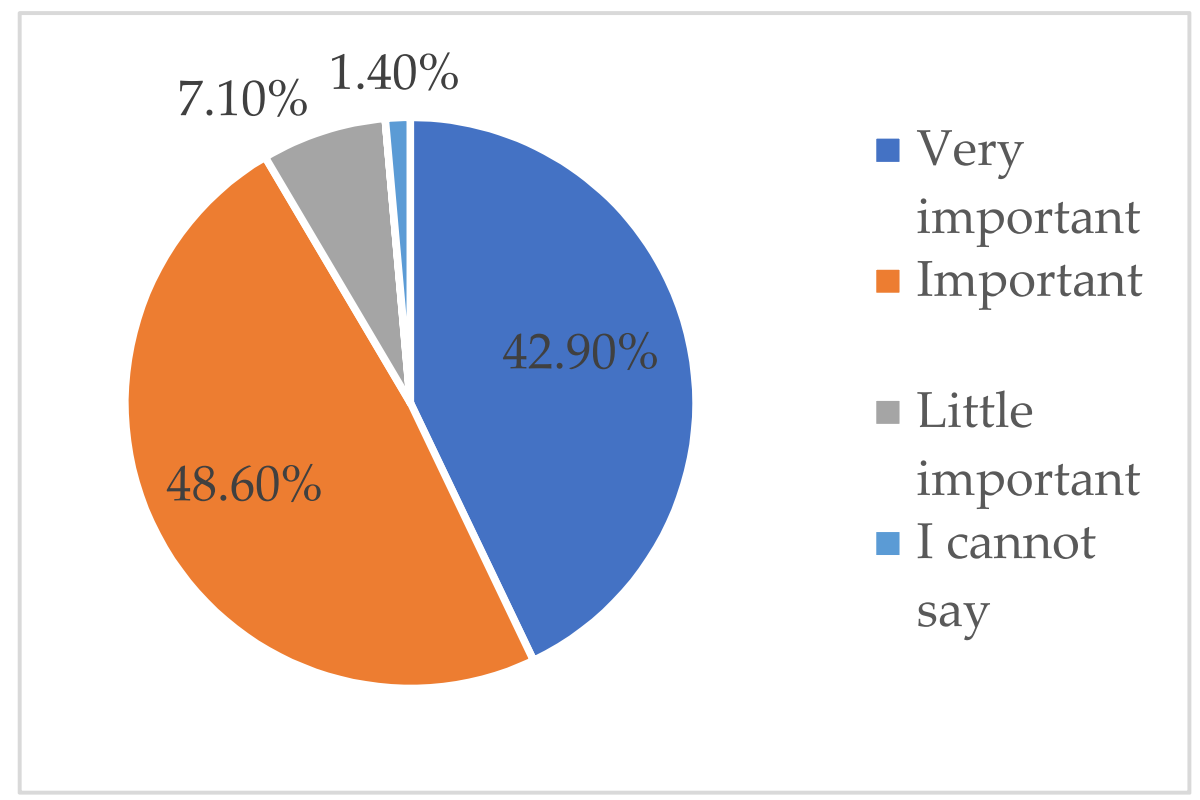

Figure 6. Importance of transfer prices.

The data presented demonstrate an awareness of the importance of transfer pricing by affiliated companies, which can help increase the sustainability of public finances. Awareness is a first step towards a responsible, ethical, less opportunistic behavior. Companies need to move from using transfer pricing as a tax manipulation tool, through which they move profits to low-tax jurisdictions, to using them as a strategic planning tool.

2. Which transactions do you consider to be most prone to a control in the field of transfer pricing? Please mark the correct answers in the options below.

The companies participating in the research consider the financing transactions within the group as the most prone to a control in the field of transfer pricing, followed equally by the management, consultancy and assistance services and the transactions with goods. In third place in terms of transactions prone to transfer pricing control is the production activity, followed by transactions involving intellectual property, royalty payments, transactions specific to financial institutions and others (Figure 7).

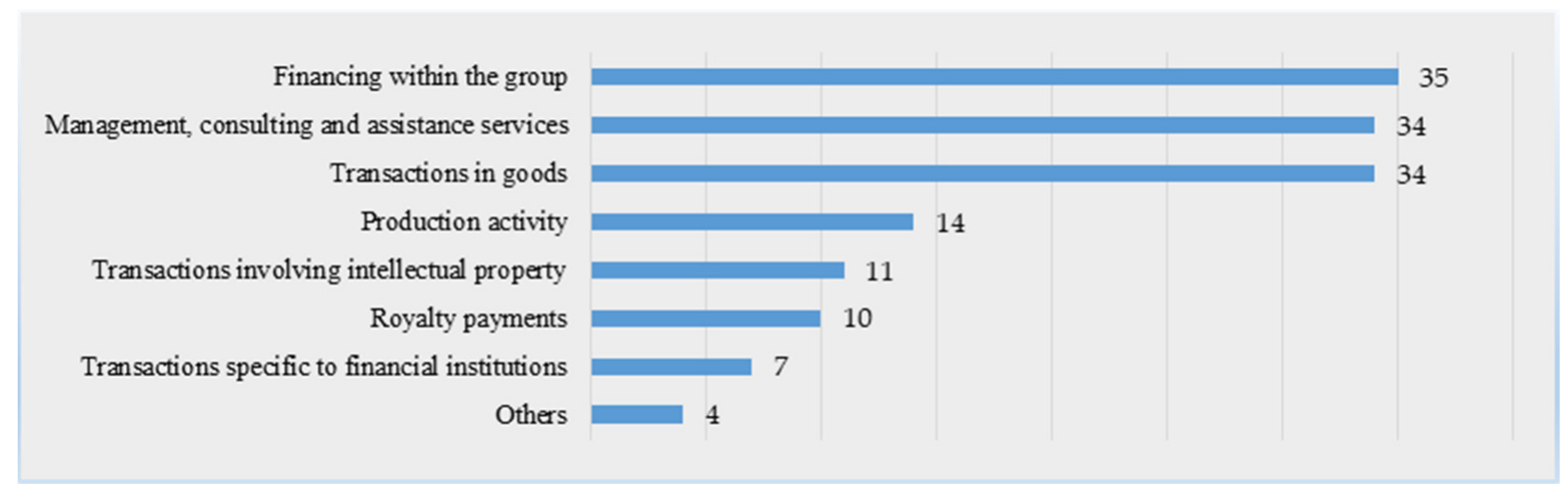

Figure 7. Transactions prone to a control in the field of transfer pricing. 
Regarding the transactions that are most prone to transfer pricing control, it should be noted that they are found in both multinational companies and small and medium-sized companies, which carry out transactions with affiliates and report profits below those related to the sector in which they operate. Small and medium-sized companies risk being unprepared in their dealings with tax authorities, as they generally have a small staff structure. In their case, it is necessary to qualify the staff involved in the management of transfer pricing by participating in professional training courses, as well as their motivation by rewarding the work done.

3. Is there a transfer pricing policy within your company?

A total of $39.10 \%$ of companies stated that the group's policy is in line with national law, $27.50 \%$ said that they have developed a transfer pricing policy based on national law, and $4.40 \%$ that the group's policy is taken over without changes to national law. Only $29.00 \%$ of companies mentioned that they do not have a transfer pricing policy (Figure 8).

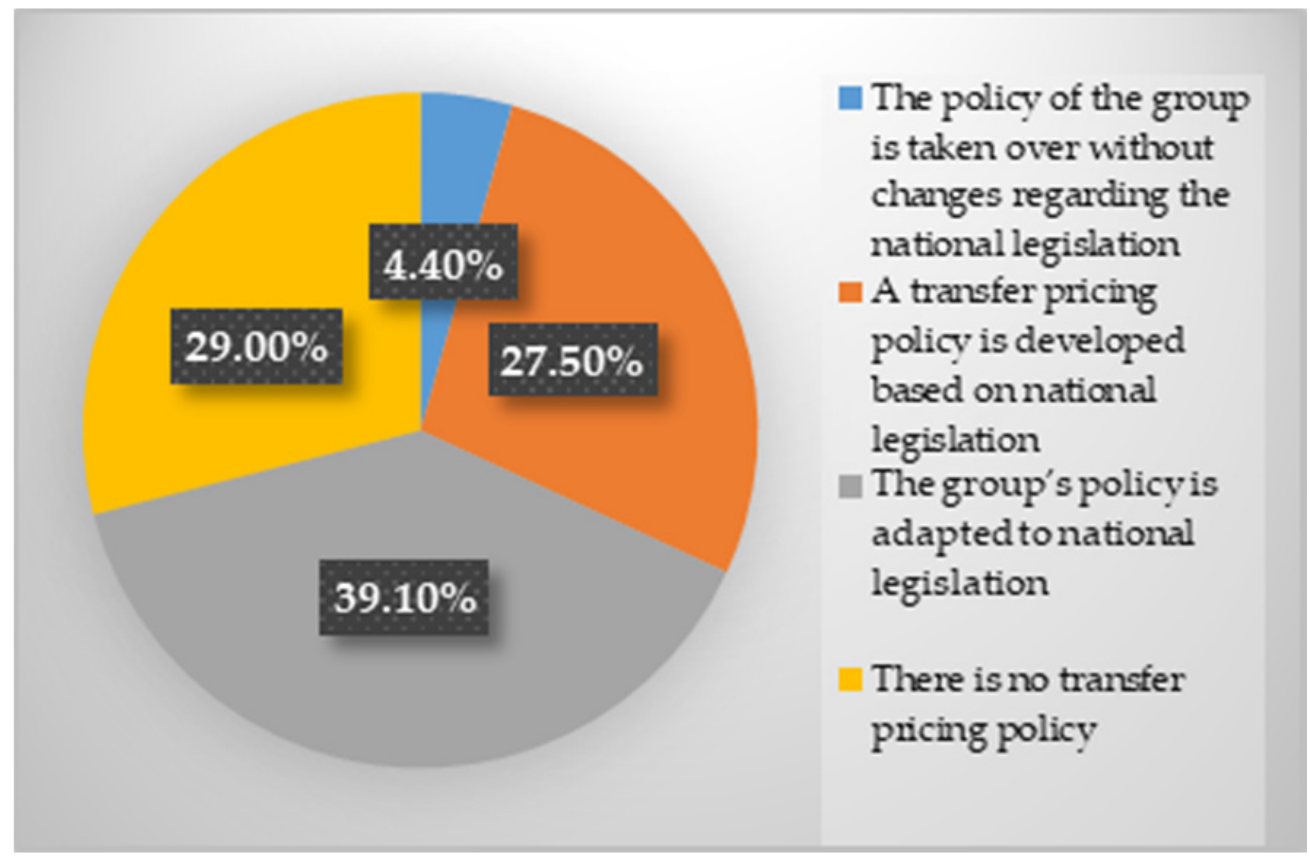

Figure 8. Transfer pricing policy.

Although the transfer pricing policy is not a mandatory legal requirement, as is the transfer pricing file, it is recommended to prevent possible non-compliance with applicable legal regulations. It is assimilated to a planning element because it establishes ways of working for all types of transactions carried out by the company with related parties and anticipates the activity of preparing the transfer pricing file. The fact that $71.00 \%$ of the companies participating in the study have a transfer pricing policy reinforces the idea of awareness of the importance of transfer pricing. In most cases, the transfer pricing policy has been developed in accordance with or adapted to national legislation, this compliance with relevant legislation being another contributing factor to increasing the sustainability of public finances.

4. Within your company, who has responsibilities in the field of transfer pricing (preparation and updating of documentation, monitoring of transfer pricing, etc.)? 
The local financial department has responsibilities in the field of transfer pricing in the case of $35.70 \%$ of the companies participating in the research, while $24.30 \%$ of the companies have outsourced the activity to a specialized company. Meanwhile, $17.20 \%$ of the surveyed companies the transfer prices are handled by the financial department at the mother company level, whereas in the case of $11.40 \%$ of the respondents the transfer prices are handled by both the local financial department and that of the mother company, and $11.40 \%$ do not know who should have responsibilities in this area (Figure 9).

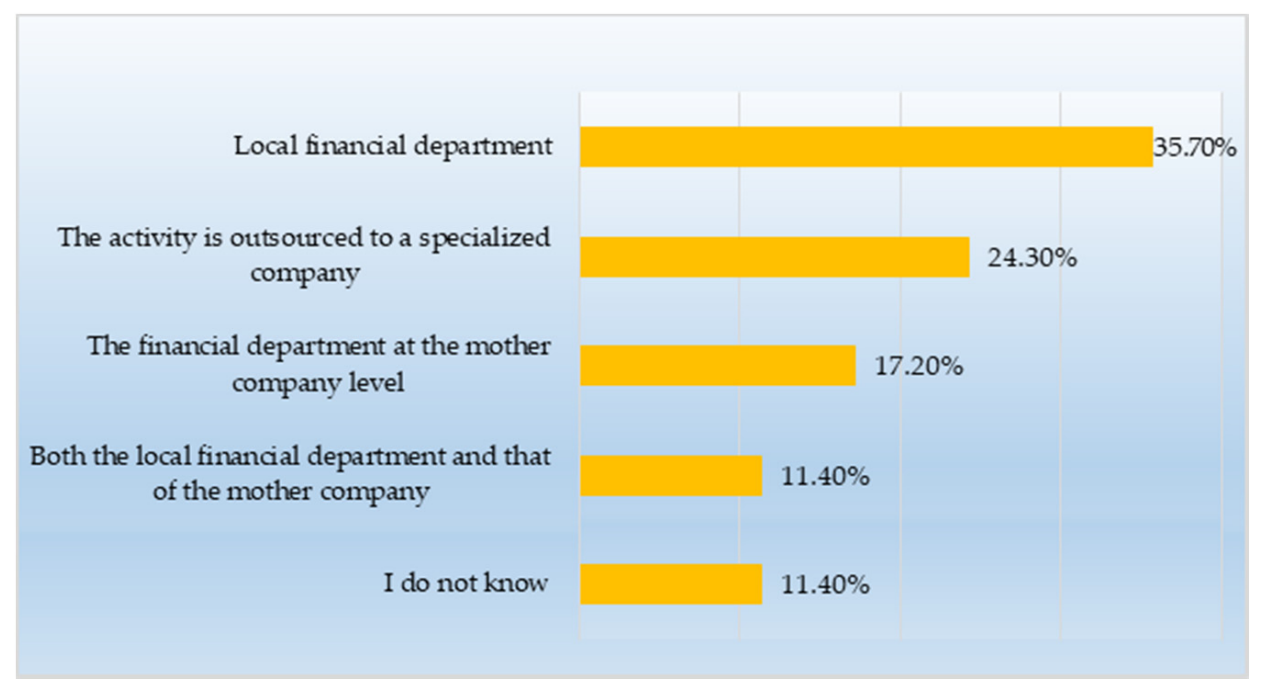

Figure 9. Duties in the field of transfer pricing.

As expected, attributions in the field of transfer pricing have the financial departments or specialized companies to which this activity is outsourced. It is a positive aspect, because through their technical expertise and knowledge in the financial-accounting field, they can contribute to increasing public confidence, which in turn contributes to increasing the sustainability of public finances.

5. Which of the following transfer pricing issues do you think have the greatest impact on your company? Please give each aspect listed below a grade from 1 (lowest impact) to 3 (highest impact).

The fiscal risk associated with transfer pricing is considered to have the greatest impact on the company, obtaining the maximum score of 3 points from a number of 37 respondents, which represents $52.86 \%$ of the companies that responded to the questionnaire. With medium impact on the company is transparency and exchange of information between tax authorities, which obtained the average score of 2 points from a number of 30 respondents, representing $42.86 \%$ of participating companies in the research. Of the three aspects mentioned in the questionnaire, the least impact on the participating companies in the research is that of the reputational risk. A number of 29 respondents, representing $41.43 \%$ of the companies that responded to the questionnaire, gave the minimum score of 1 point to this aspect (Figure 10). 


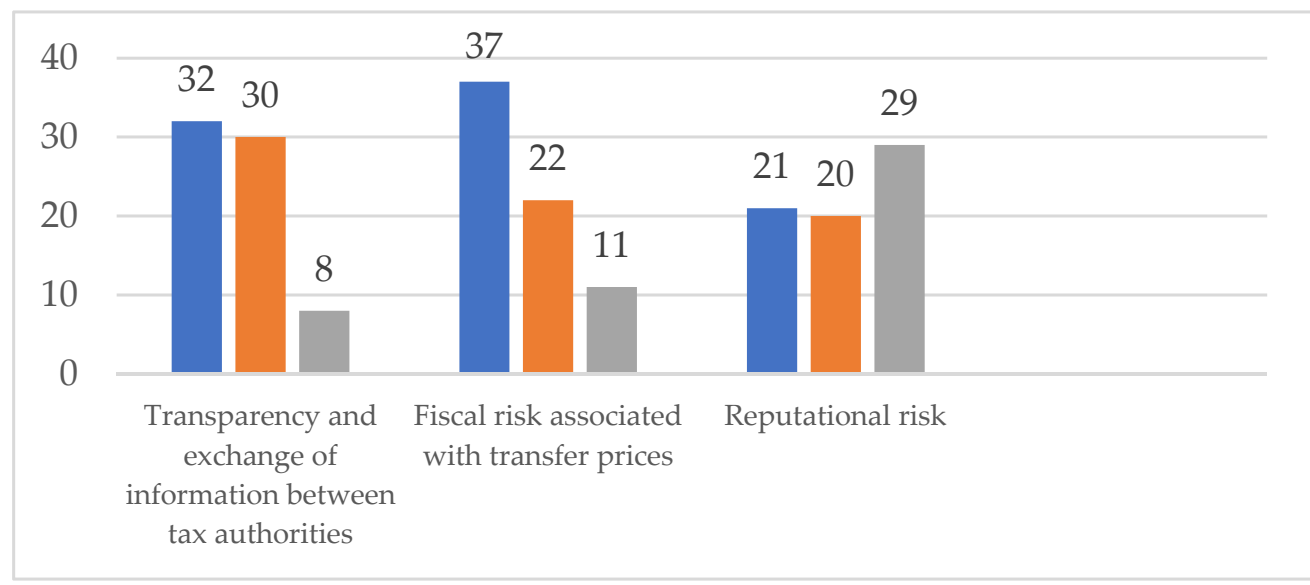

Figure 10. Transfer pricing issues with an impact on the company. Note: Blue-the biggest impact; Orange-average impact; Gray—-the lowest impact.

Although the fiscal risk, i.e., the risk of being controlled in the field of transfer pricing, is considered to have the greatest impact on the company, the other two aspects specific to the transfer pricing that were studied are not neglected by the respondents, being closely related to each other. Proper knowledge and management of the implications of the three specific aspects of transfer pricing, with an impact on affiliated companies, are contributions to ensuring the sustainability of public finances.

6. What do you think are the biggest problems faced by companies that conduct transactions with related parties?

Legislation that leaves room for interpretation ranks first in the problems faced by companies conducting transactions with affiliated parties, followed in second place by the costs of preparing transfer pricing documentation, and double taxation in third place. The reporting mechanism and the increased number of controls in the field of transfer pricing are at the bottom of the top-ranked problems faced by affiliated companies (Figure 11).

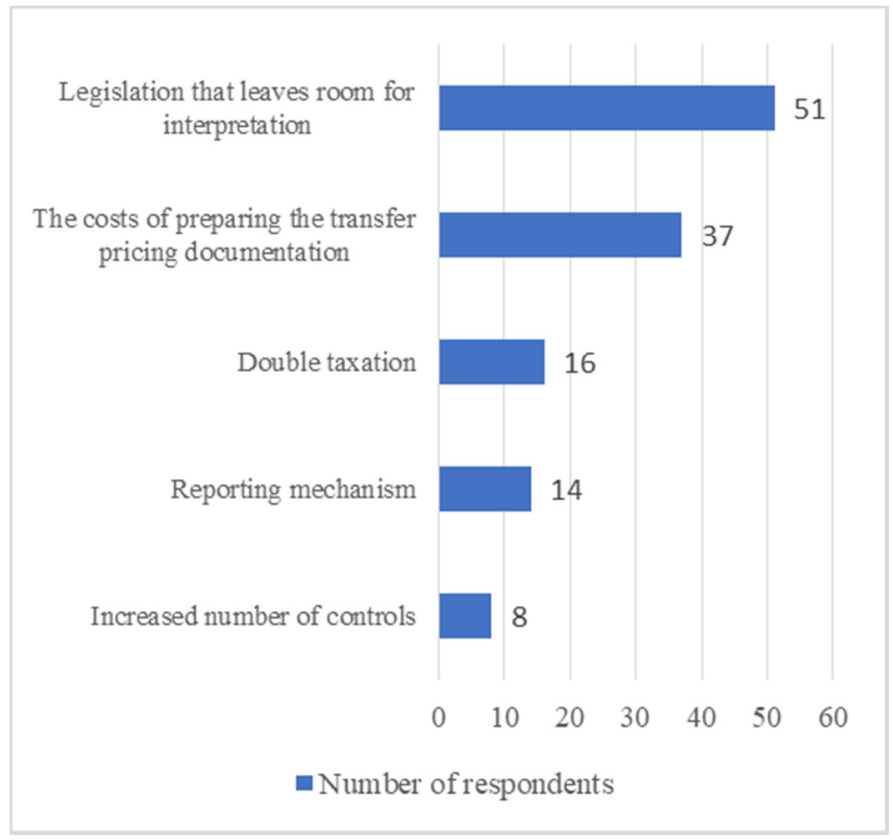

Figure 11. Top problems of affiliated companies. 
Affiliate companies consider transfer pricing legislation to be one of the biggest problems, as it can give rise to additional financial costs or double taxation. In order to reduce the effects of these issues, with a direct impact on public budget revenues, policy makers should be more involved in drafting clear legislation that leaves no room for interpretation.

7. How do you prepare the transfer pricing documentation?

A total of $44.30 \%$ of the companies participating in the research regularly update the transfer pricing documentation. A large number of companies $(28.60 \%)$ say that they have not prepared the transfer pricing documentation, while $22.90 \%$ of those surveyed prepare it only at the request of the control authorities (Figure 12).

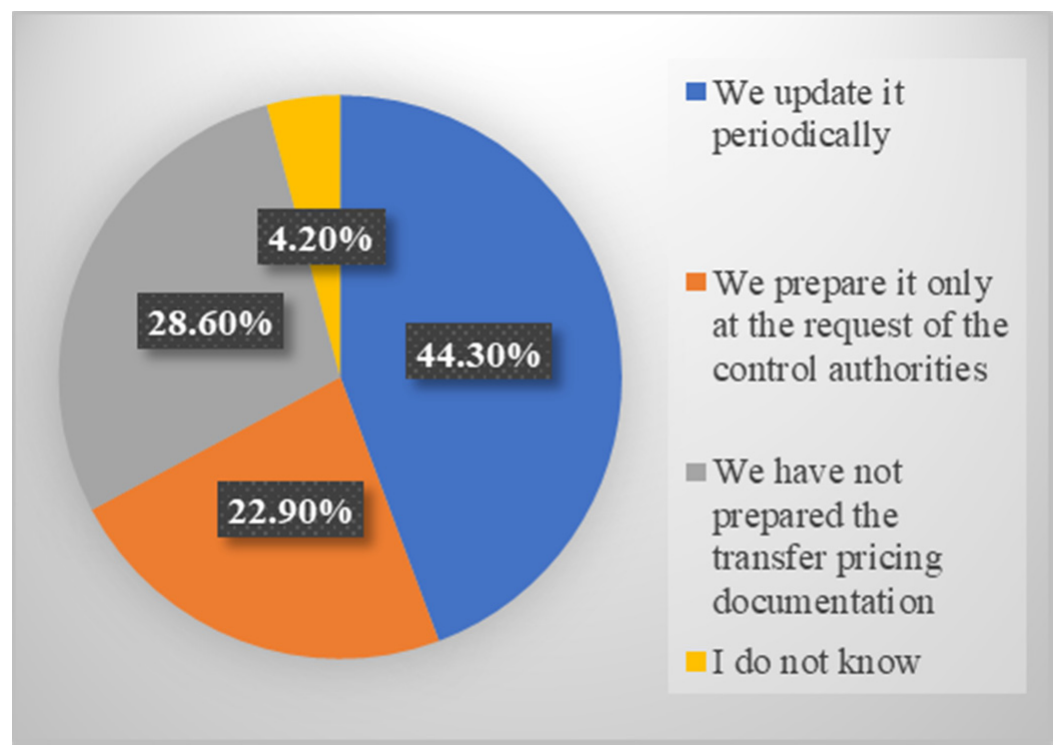

Figure 12. Transfer pricing documentation.

Transfer pricing documentation is a set of actions that a company takes to justify compliance with the market value principle of transfer pricing in transactions between related parties and is completed through the transfer pricing file. This is the responsibility of the taxpayer and should be given due weight. Through properly prepared transfer pricing documentation, through accurate reporting, companies can help build sustainable public finances.

8. Have you been subject to a tax inspection in the field of transfer pricing in the last 5 years?

A total of $25.70 \%$ of the companies participating in the research have been subject to a tax inspection in the field of transfer pricing in the last 5 years. Most respondent companies $(65.70 \%)$ have not been subject to a tax inspection in the field of transfer pricing in the last 5 years (Figure 13). 


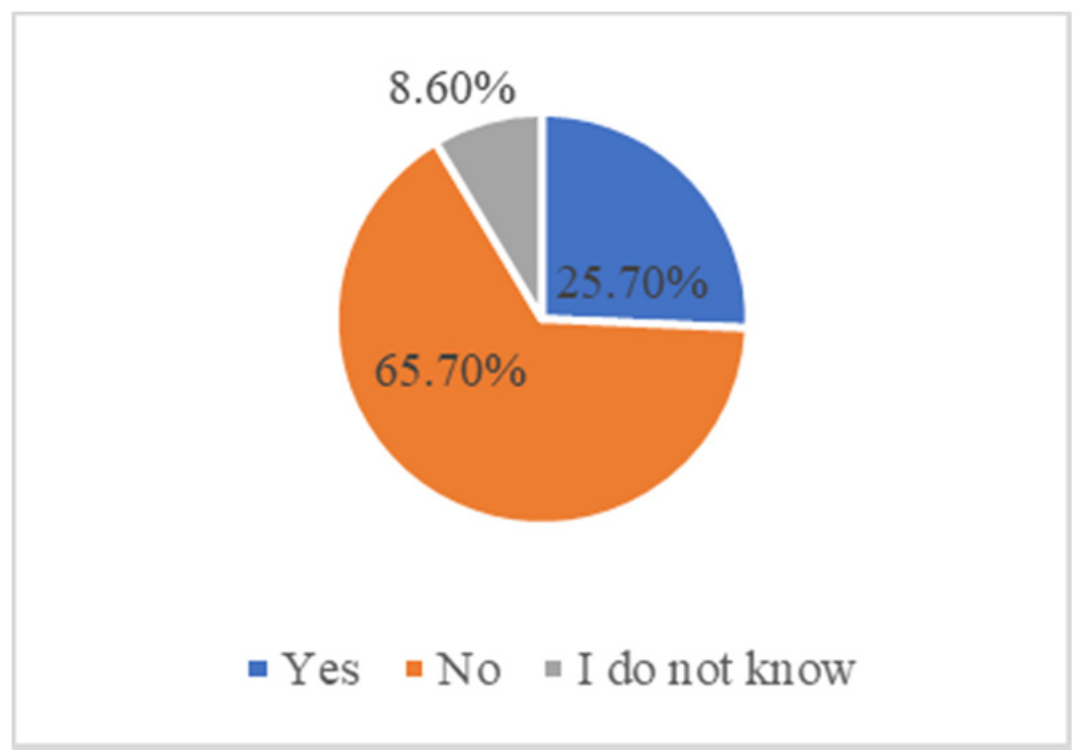

Figure 13. Tax inspections.

Although most of the companies participating in the study have not been subject to a tax inspection in the field of transfer pricing in the last five years, they must be prepared in this regard, as ANAF Romania shows an intense concern for intra-group transactions and profits transfer actions. The levers that ANAF has at its disposal for identifying potential risks and initiating controls should not be neglected. Through the actions taken, the Romanian tax authority is interested in collecting more amounts to the state budget.

9. To reduce the tax risk associated with transfer pricing, have you so far resorted to an "Advance Price Agreement"?

A total of $80 \%$ of the surveyed companies have not yet resorted to an advance price agreement. Only $5.70 \%$ of the companies participating in the study have so far used an advance price agreement (Figure 14).

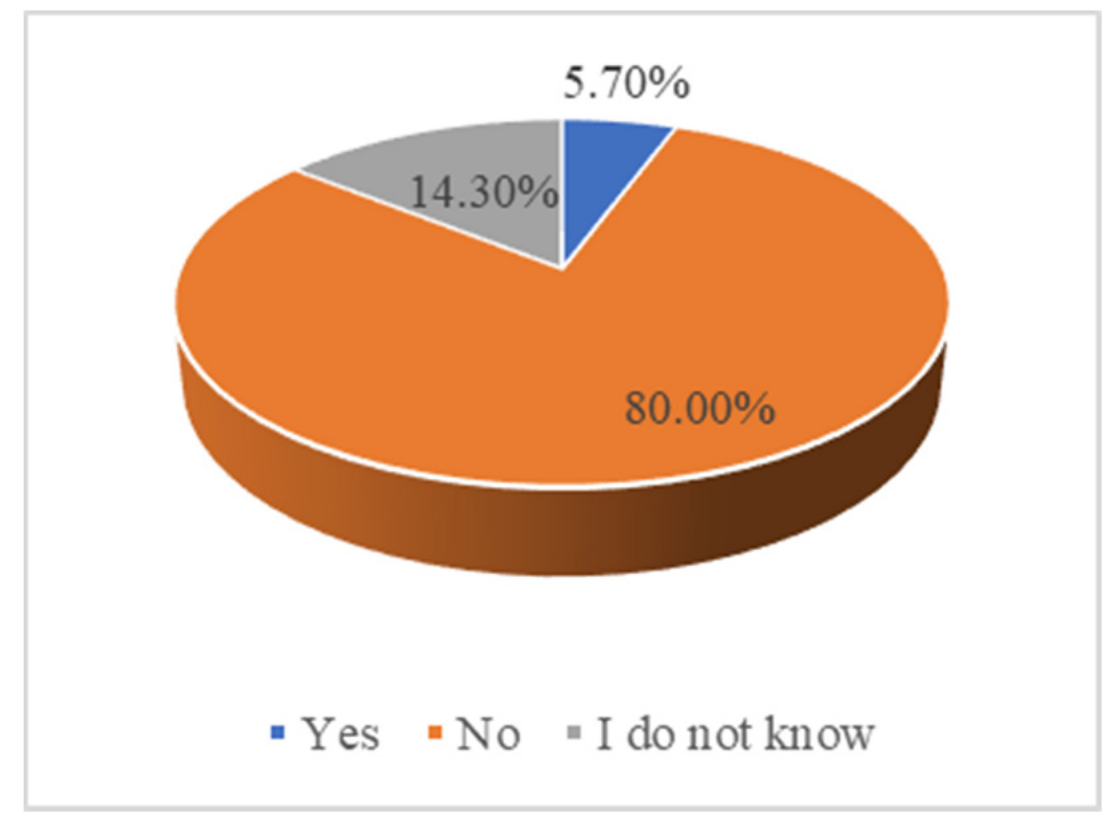

Figure 14. Advance Price Agreement. 
The advance price agreement is a way for taxpayers to carry out transactions of significant value and of a complex nature with related parties, a way to protect themselves from possible adjustments by the tax authorities. However, the vast majority of companies participating in the study have so far not resorted to such an instrument of protection; this is possibly due to the high costs involved in issuing a price agreement in advance and the complicated issuance procedures.

10. Do you think that the ongoing global reforms in the field of profit taxation will affect your company in the next period?

A total of $55.70 \%$ of the surveyed companies consider that it is possible that the global reforms in progress in the field of profit taxation will affect the company, while $7.20 \%$ consider that they will be affected by these reforms. At the same time, a percentage of $25.70 \%$ of those surveyed are not aware of the reforms in the field of profit taxation, and $11.40 \%$ of companies believe that they will not be affected (Figure 15).

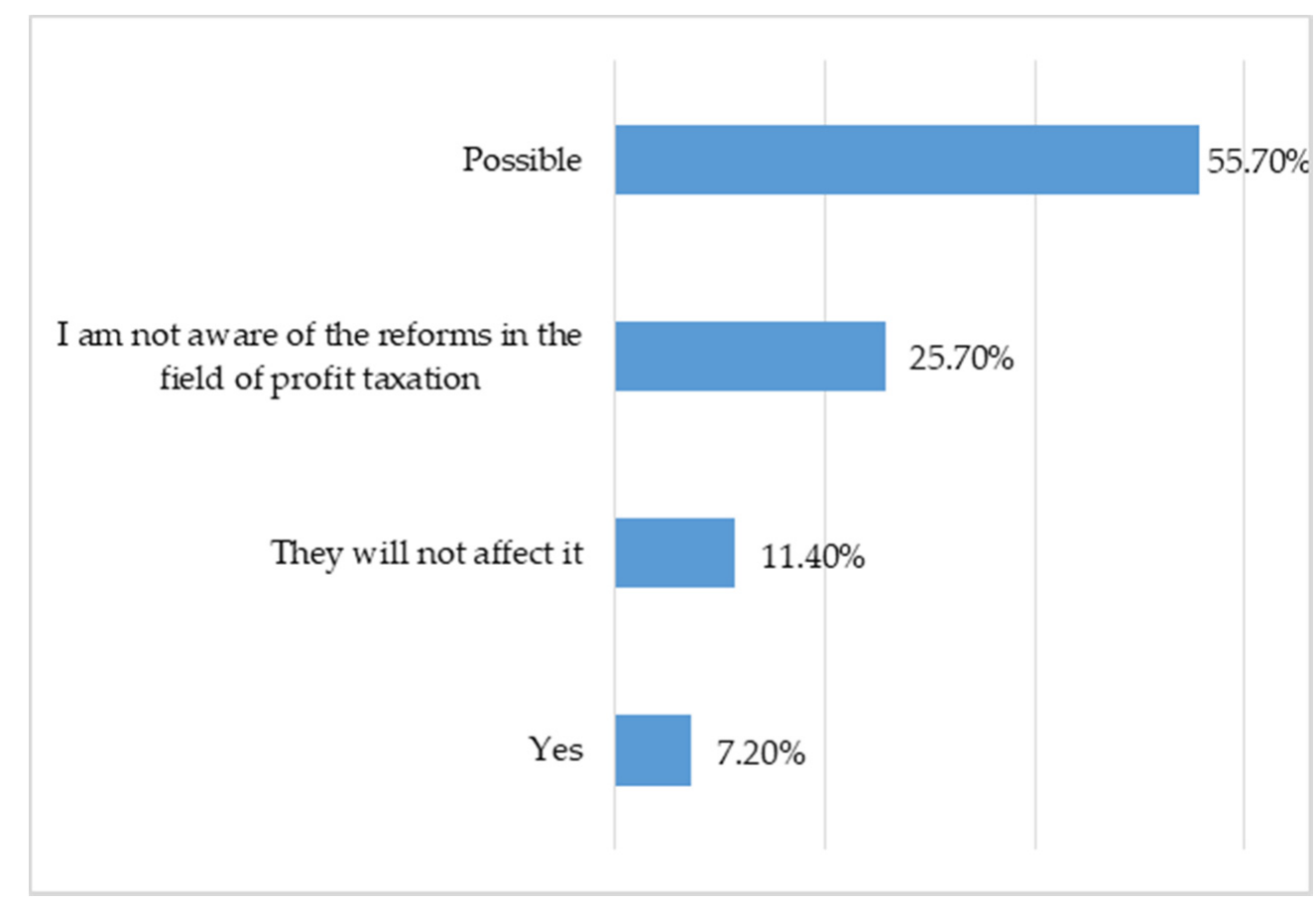

Figure 15. Impact of reforms in the field of profit taxation.

\section{Limits of the Research}

Although the empirical research has a very important role in taking the pulse of real life of companies that have transactions with affiliated parties, the methods and tools of the used empirical research have generated the emergence of some research limitations, which we briefly present below:

$>\quad$ An in-depth analysis of the way in which companies approach transfer prices and the associated risks could not be performed. Certain aspects were selected, which, according to the own professional reasoning and theoretical knowledge, doubled by practical experience, were considered relevant.

$>$ We are aware that not all current issues related to transfer pricing could be addressed in the research.

$>$ The use of the questionnaire as a research method can generate cases of insincerity, superficiality, omission or answers marked by desirability from the respondents.

$>$ Although it was mentioned in the questionnaire that it is anonymous and the answers are confidential, sending the questionnaire by email, nominally to a person, creates the idea of controlling anonymity, which may have determined a degree of reluctance. 
$>$ The specificity of transfer pricing is one with fiscal and reputational implications. Using the Likert Scale on some questions can help provide answers that are not the ones in the company's reality, but are the ones that theoretically should be.

$>$ The elements of the sample included in the study were selected using the own professional reasoning.

\section{General Conclusions}

Our paper, meant to sound an alarm about the impact that transfer pricing can have on the sustainability of public finances, reveals interesting concluding remarks as a result of the questionnaire distributed to various companies from the Sibiu area of Romania.

First of all, affiliated companies are aware of the high attention that tax authorities pay to intra-group transactions and actions aimed at shifting profits between tax jurisdictions with different tax rates, so as to ultimately minimize corporate tax.

As it results from the analysis of the answers received from the companies participating in the research, a large number have a transfer pricing policy or regularly update their transfer pricing documentation. In most cases, responsibilities in the field of transfer pricing belong to the local financial department or the activity is outsourced to a specialized company. We can consider the involvement of financial-accounting professionals in the management of transfer pricing as a way to increase public confidence in governments, which in turn contributes to increasing the sustainability of public finances.

The transactions considered by the responding companies to be the most prone to transfer pricing control are those of financing within the group, followed equally by management, consulting, assistance and goods transactions.

In the context of a legislation that leaves room for interpretation, and of a high number of controls in the field of transfer pricing, we notice a small number of companies that have used the Advance Price Agreement as a tool to reduce the tax risk associated with transfer pricing and also an uncertainty about how the ongoing global tax reforms in the field of profit taxation will affect companies in the next period. The issues presented have a direct impact on public budget revenues. A clear legislation, which leaves no room for interpretation, as well as effective communication with companies are needed to strengthen public finances.

However, the results of the in-depth analysis of the responses obtained from the distribution of the questionnaire demonstrated responsibility and involvement on the part of companies conducting transactions with affiliated parties, by taking measures to properly manage transfer pricing and the associated risks.

Although our research demonstrates a recognition of the importance of transfer pricing by affiliated companies participating in the study, there are companies that do not have a transfer pricing policy, possibly due to ignorance of the benefits they offer. We recall its advantage of providing elements that are easily included in the transfer pricing file without additional costs, either financial or time costs, as well as the contribution to creating a responsible company image.

Even if the questionnaire results indicate that the tax risk associated with transfer pricing is considered to have the greatest impact on the company, and interpretable legislation is one of the major issues, a significant number of respondents are unaware of profit tax reforms or have not resorted to a price agreement in advance. The cause may be the fact that Romania has a relatively short experience in the field of transfer pricing as compared to other countries, being an area where both companies and authorities still have much to improve.

Entities for which the transfer pricing reporting mechanism and controls are not a problem may not yet realize their importance, as well as the fact that transfer pricing affects not only the fiscal company but also the performance indicators or its cash flow.

Affiliated companies contribute to ensuring the sustainability of public finances through actions aimed at the proper management of transfer pricing from a legislative perspective, compliance with the market value principle, fair reporting and avoiding profit 
shifting actions in order to minimize corporate tax. At the same time, ANAF Romania participates in ensuring the sustainability of public finances through the controls it carries out in the field of transfer pricing and which can be finalized with additional fiscal obligations established to those controlled.

In order to keep up with the global reforms proposed by the EU and the OECD in the field of profit taxation, companies need to find new solutions to cope with changes through: documentation, staff training, adaptation of IT and reporting systems, and building a favorable image in relation to the authorities and the general public. All these actions indirectly contribute to increasing the sustainability of public finances.

Author Contributions: Conceptualization, I.T.; Data curation, M.P.L.; Formal analysis, M.P.L.; Investigation, M.P.L.; Methodology, M.P.L.; Project administration, I.T.; Supervision, I.T.; Writing-review and editing, I.T. Both authors have read and agreed to the published version of the manuscript.

Funding: This research received no external funding.

Institutional Review Board Statement: Ethical review and approval were waived for this study, due to following reasons: the questionnaire was anonymous, and the respondents completed it by entering each individually the computer application People friendly forms and surveys, available at https:/ / www.typeform.com/ (accessed on 2 January 2021).

Informed Consent Statement: Accessing the application People friendly forms and surveys implies consent. In the centralized situation of the received answers, the name of the respondent company cannot be identified, which guaranteed the respondents' privacy.

Data Availability Statement: Data sharing is not applicable to this article.

Conflicts of Interest: The authors declare no conflict of interest.

$\begin{array}{ll}\text { Abbreviations } \\ \text { ANAF } & \text { The National Agency for Fiscal Administration } \\ \text { BEPS } & \text { Base Erosion and Profit Shifting } \\ \text { CAWI } & \text { Computer Assisted Web Interviewing } \\ \text { ICAEW } & \text { Institute of Chartered Accountants in England and Wales } \\ \text { MFP } & \text { Ministry of Public Finance } \\ \text { OECD } & \text { The Organization for Economic Co-operation and Development } \\ \text { GDP } & \text { Gross Domestic Product } \\ \text { TEI } & \text { The Tax Executives Institute } \\ \text { VAT } & \text { Value Added Tax }\end{array}$

\section{References}

1. Legea nr. 227/2015 Privind Codul Fiscal. M.O. nr. 688/2015 [Law no. 227/2015 on the Fiscal Code. Official Monitor no. 688/2015]. Available online: https://static.anaf.ro/static/10/Anaf/legislatie/L_227_2015.pdf (accessed on 2 April 2021).

2. OCDE. Ghidul_Linii Directoare Privind Prețurile de Transfer Pentru Companiile Multinaționale și Administrațiile Fiscale. 2017. [OECD. Guide-Transfer Pricing Guidelines for Multinational Companies and Tax Administrations. 2017]. Available online: https: / / www.oecd.org/tax/transfer-pricing/oecd-transfer-pricing-guidelines-for-multinational-enterprises-and-taxadministrations-20769717.htm (accessed on 2 April 2021).

3. Guvernul României-Ministerul Finanțelor. Raportul Privind Situaţia Macroeconomică pe Anul 2020 şi Proiecţia Acesteia pe Anii 2021-2023. 2020. [Government of Romania-Ministry of Finance. Report on the Macroeconomic Situation for 2020 and Its Projection for 2021-2023. 2020]. Available online: https:/ / www.senat.ro/legis/PDF/2019/19L627B995.pdf (accessed on 2 April 2021).

4. Ordin ANAF nr. 3.281/2020 Pentru Modificarea Ordinului preşedintelui Agenţiei Naţionale de Administrare Fiscală nr. $3769 / 2015$ Privind Declararea Livrărilor/Prestărilor şi Achiziţiilor Efectuate pe Teritoriul Naţional de Persoanele Înregistrate în Scopuri de TVA şi Pentru Aprobarea Modelului şi Conţinutului Declaraţiei Informative Privind Livrările/Prestările şi Achiziţiile Efectuate pe Teritoriul Naţional de Persoanele Înregistrate în Scopuri de TVA. [ANAF Order no. 3.281/ 2020 for the Modification of the Order of the President of the National Agency for Fiscal Administration no. 3769/2015 Regarding the Declaration of Deliveries/ Services and Acquisitions Made on the National Territory by the Persons Registered for VAT Purposes and for the Approval of the Model and Content of the Informative Declaration Regarding the Deliveries/Services and Acquisitions Made on the National Territory by the Persons Registered for VAT Purposes]. Available online: https://static.anaf.ro/static/10/Anaf/legislatie/ OPANAF_3281_2020.pdf (accessed on 2 April 2021). 
5. ANAF România. Raport de Performanță 2019. 2019. [ANAF Romania. Performance Report 2019. 2019]. Available online: https://static.anaf.ro/static/10/Anaf/Informatii_R/Raport_performanta_07072020.pdf (accessed on 2 April 2021).

6. Guvernul României-Ministerul Finanțelor. Raportul Privind Situația Macroeconomică pe Anul 2021 și Proiecția Acesteia pe Anii 2022-2024. 2021. [Government of Romania-Ministry of Finance. Report on the Macroeconomic Situation for 2021 and its Projection for 2022-2024. 2021]. Available online: https://mfinante.gov.ro/static/10/Mfp/resurse/transparenta/ proiectbugetdestat2021/Raportbuget2021.doc (accessed on 2 April 2021).

7. Legea nr. 69/2010 a Responsabilităţii Fiscal-Bugetare, Republicată. M.O. nr. 472/2020. [Law no. 69/2010 of the Fiscal-Budgetary Responsibility, Republished. Official Monitor no. 472/2020]. Available online: http:/ /legislatie.just.ro/Public/DetaliiDocument/ 118059 (accessed on 2 April 2021).

8. Consiliul Fiscal al României. Opinia Consiliului Fiscal Privind Legea Bugetului de Stat. Legea Bugetului de Asigurări Sociale Pentru Anul 2021 și Strategia Fiscal-Bugetară 2021-2023. 2021. [The Fiscal Council of Romania. Opinion of the Fiscal Council on the State Budget Law. Law on the Social Insurance Budget for 2021 and Budget Fiscal Strategy 2021-2023. 2021]. Available online: http:/ / www.consiliulfiscal.ro/Opinie\%20CF\%20buget\%202021\%20si\%20SFB.pdf (accessed on 2 April 2021).

9. European Commission. European Semester Thematic Factsheet. Susteinability of Public Finances. Available online: https: / / ec.europa.eu/info/sites/default/files/european-semester_thematic-factsheet_public-finance-sustainability_en.pdf (accessed on 23 May 2021).

10. Davies, R.B.; Martin, J.; Parenti, M.; Toubal, F. Knocking on Tax Haven's Door: Multinational Firms and Transfer Pricing. Rev. Econ. Stat. 2018, 100, 120-134. [CrossRef]

11. Bloomberg Tax. Available online: https://news.bloombergtax.com/transfer-pricing/tax-scrutiny-and-transfer-pricing-whatyou-can-expect-in-2021 (accessed on 23 May 2021).

12. ICAEW (Institute of Chartered Accountants in England and Wales). Available online: https://www.ifac.org/system/files/news/ files/ICAEW\%20Sustainable\%20public\%20finances\%20global\%20views.pdf (accessed on 23 May 2021).

13. Ernst \&Young Global Limited. Transfer Pricing and International Tax Survey-How Profound Change, Transparency and Controversy are Reshaping a Critical Business Function. 2019. Available online: https://www.ey.com/en_gl/transfer-pricinginternational-tax-survey (accessed on 2 April 2021).

14. KPMG. Transfer Pricing and Trade and Customs Services. KPMG LLP-Transfer Pricing and Trade Compliance Survey. 2020. Available online: https://tax.kpmg.us/articles/2020/transfer-pricing-trade-compliance-survey-2020.html (accessed on 2 April 2021).

15. Bakertilly International. International Tax Survey Priorities and Challenges Facing Multinationals-2019/2020. 2020. Available online: https:/ / www.bakertilly.global/media/7594/bt_taxsurvey_200317-print.pdf (accessed on 2 April 2021).

16. Klassen, K.J.; Lisowsky, P.; Mescall, D. Transfer pricing: Strategies, practices, and tax minimization. Contemp. Account. Res. 2017, 34, 455-493. [CrossRef]

17. Hendratama, T.D.; Barokah, Z. Related party transactions and firm value: The moderating role of corporate social responsibility reporting. China J. Account. Res. 2020, 13, 223-236. [CrossRef]

18. PKF Finconta. Preţurile de Transfer în România. 2018, 2020. [PKF Finconta. Transfer Prices in Romania. 2018, 2020]. Available online: https:/ / www.slideshare.net/FlorentinaSusnea/studiu-pkf-finconta-preurile-de-transfer-n-romnia-2018 (accessed on 2 April 2021).

19. Jonker, J.; Pennink, B. The Essence of Research Methodology: A Concise Guide for Master and Ph.D. Students in Management Science; Springer: Berlin, Germany, 2010.

20. Vanderstoep, S.; Johnston, D. Research Methods for Everyday Life; Jossey-Bass Wiley: San Francisco, CA, USA, 2009.

21. Babbie, E.R. The Practice of Social Research; Thomson Wadsworth: Belmont, CA, USA, 2007.

22. Lancaster, G. Research Methods in Management; Elsevier Butterworth-Heinemann: Oxford, UK, 2005.

23. Oprean, C. Metode și Tehnici ale Cunoașterii Științifice; Editura Universităţii Lucian Blaga Sibiu: Sibiu, Romania, 2006. [Oprean, C. Methods and Techniques of Scientific Knowledge; Lucian Blaga University of Sibiu Publishing House: Sibiu, Romania, 2006].

24. Butnaru, I.; Simionescu, A. Challenges and Trends in 2019-Transfer Pricing. In Proceedings of the Challenges and Trends in Taxation in 2019, Sibiu, Romania, 3 June 2019.

25. Guvernul României-Ministerul Finanțelor Publice. Strategia Fiscal Bugetară Pentru Perioada 2019-2021. 2019. [Government of Romania-Ministry of Public Finance. Budget Fiscal Strategy for the Period 2019-2021. 2019]. Available online: https: //mfinante.gov.ro/static/10/Mfp/transparenta/SFB2019-2021en_05062019.pdf (accessed on 2 April 2021). 